\title{
Properties of three iridovirus-like agents associated with systemic infections of fish
}

\author{
R. P. Hedrick ${ }^{1}$, T. S. McDowell ${ }^{1}$, W. Ahne ${ }^{2}$, C. Torhy ${ }^{3}$, P. de Kinkelin ${ }^{3}$ \\ ${ }^{1}$ Department of Medicine, University of California, Davis, California 95616 USA \\ ${ }^{2}$ Institut für Zoologie und Hydrobiologie der Universität München, Kaulbachstraße 37, W-8000 München 22, Germany \\ ${ }^{3}$ Unité de Virologie et d'Immunologie Moléculaires, INRA, F-78350 Jouy-en-Josas, France
}

\begin{abstract}
Three iridovirus-like agents associated with systemic infections in fish were examined by electron microscopy, gel electrophoresis of virion polypeptides and serological cross reactions with hyperimmune rabbit sera. The virus associated with epizootic hematopoietic necrosis (EHN) of redfin perch Perca fluviatilis in Australia, the virus from sheatfish Siluris glanis in Germany and a recently isolated iridovirus-like agent from catfish Ictalurus melas in France shared similar virion morphology and size, number and weight of structural polypeptides and common antigens as shown by cross immunofluorescence tests. The characteristics of these 3 piscine viruses and their striking similarity to frog virus 3, the type strain of the Ranavirus genus in the family Iridoviridae, suggest that they should be grouped into the same genus. The presence of similar agents in fish and amphibians emphasizes the potential adaptation and evolution of serious viral pathogens among these aquatic hosts and further complicates programs aimed at preventing or controlling the spread of fish viruses.
\end{abstract}

\section{INTRODUCTION}

The role of iridoviruses or iridovirus-like agents as causes of epidermal (lymphocystiviruses) and blood cell disorders (erythrocytic necrosis viruses) in fish is well known (Wolf 1988). Only in the past 5 yr have iridovirus-like agents been recognized as causes of serious systemic diseases among feral, cultured, and ornamental fish populations (Langdon et al. 1986, Ahne et al. 1989, Armstrong \& Ferguson 1989, Pozet et al. 1992). Few properties of these systemic agents have been described but their morphological and biological characteristics clearly separate them from the piscine iridoviruses or iridovirus-like agents associated with lymphocystis, erythrocytic necrosis, cod ulcus syndrome, eel and cyprinid infections (Wolf 1988) or the recently described epidermal infections in sturgeon (Hedrick et al. 1990).

Three iridovirus-like agents causing systemic diseases in fish have been isolated using established fish cell lines. Epizootic hematopoietic necrosis (EHN) was the first serious systemic iridovirus-like infection isolated from fish (Langdon et al. 1986). Most major organs were affected but the severe necrosis in the renal and splenic hematopoietic tissues characterized the disease in a feral population of redfin perch Perca fluviatilis from Australia. Additional outbreaks due to the virus (EHNV) among redfin perch (Langdon \& Humphrey 1987) and rainbow trout Oncorhynchus mykiss were reported later (Langdon \& Humphrey 1987, Langdon et al. 1988). The potential host range of EHNV was shown to include at least 7 species of teleost fish (Langdon 1989). The biochemical and physical properties of the agent causing EHNV have recently been examined and confirm its affinity with the Iridoviridae (Eaton et al. 1991).

A second systemic iridovirus-like agent was isolated by Ahne et al. (1989) from sheatfish Silurus glanis experiencing a $100 \%$ mortality at an intensive warmwater aquaculture facility in northwestern Germany. The serious pathogenic nature of the virus from sheatfish was demonstrated in experimental studies by Ahne et al. (1990) and Ogawa et al. (1990). Losses up to $30 \%$ among adult market-sized sheatfish have also been attributed to the virus, which further stresses its potential economic impacts on cultured fish populations (Ahne et al. 1991).

A third iridovirus-like agent associated with systemic infections has recently been isolated from catfish Ictalurus melas in France (Pozet et al. 1992). A fourth systemic iridovirus-like agent with possible relationships to the 3 isolated viruses was found among dis- 
eased chromide cichlids Etropus maculatus imported from Malaysia, but attempts to isolate the virus were unsuccessful (Armstrong \& Ferguson 1989).

All 4 of these iridovirus-like agents induce similar diseases and the virus particles are of similar size and shape. The purpose of the present paper is to describe, in a side-by-side comparison, properties of the 3 agents isolated in cell culture with respect to virion size and shape, number and molecular weights of structural proteins and antigenic relationships by cross indirect fluorescent antibody tests.

\section{MATERIALS AND METHODS}

Viruses. The EHNV (13.91) used in this study was isolated from redfin perch in Australia (Langdon et al. 1986). The iridovirus-like agent (62.90) was isolated from sheatfish in Germany (Ahne et al. 1989). The third virus (59.90) was isolated from catfish in France (Pozet et al. 1992). All fish viruses were plaque-purified by 3 successive passages in the BF-2 line (CL 91; Wolf et al. 1966) from bluegill Lepomis macrochirus prior to use. Frozen stocks of all 4 viruses were stored at -70 to $-80^{\circ} \mathrm{C}$. Frog virus 3 (FV 3 ) obtained directly from the American Type Culture Collection (VR-567) was grown in the epithelioma papilloma cyprini (EPC) line (Fijan et al. 1983).

Cell line and virus propagation. The BF-2 and EPC lines were maintained in minimal essential medium (MEM) with Earle's salts supplemented with $10 \%$ fetal bovine serum (FBS; HyClone Lab. Inc., Logan, Utah, USA) $50 \mathrm{IU} \mathrm{ml} \mathrm{m}^{-1}$ of penicillin, $50 \mu \mathrm{g} \mathrm{ml}^{-1}$ of streptomycin and $2 \mathrm{mM}$ L-glutamine. Cells were propagated in either $150 \mathrm{~cm}^{2}$ flasks or 24 -well dishes at $20^{\circ} \mathrm{C}$. For virus propagation, cells were infected at a multiplicity of infection (MOI) of 5 plaque-forming units (PFU) $\mathrm{cell}^{-1}$. After adsorption for $30 \mathrm{~min}$ at $25^{\circ} \mathrm{C}, 20 \mathrm{ml}$ of MEM with $2 \%$ FBS was added to each of twenty $150 \mathrm{~cm}^{2}$ flasks containing BF-2 cells which were then incubated at $20^{\circ} \mathrm{C}$ until cytopathic effects (CPE) were complete (ca 4 to $6 \mathrm{~d}$ )

Virus purification. When CPE were complete, infected cells were frozen at $-70^{\circ} \mathrm{C}$. After thawing, the suspensions were centrifuged at $5000 \times g$ for $15 \mathrm{~min}$ to remove cellular debris. Virus in the supernatant was collected by centrifugation at $90000 \times g$ for $35 \mathrm{~min}$. The virus pellet resuspended in $2.0 \mathrm{ml}$ of TNE buffer $150 \mathrm{mM}$ Tris- $\mathrm{HCl}, \mathrm{pH} 7.5 ; 150 \mathrm{mM} \mathrm{NaCl} ; 1 \mathrm{mM}$ disodium EDTA) was layered onto a $10 \mathrm{ml}, 10$ to $60 \%$ $(\mathrm{w} / \mathrm{v})$ linear sucrose gradient in TNE. After centrifugation at $90000 \times g$ for $30 \mathrm{~min}$, the virus bands were removed and dialyzed against 1000 volumes of TNE. Virus collected in this fashion was used immediately for negative-staining electron microscopy or for polyacrylamide gel electrophoresis.
Electron microscopy. Virus preparations were negatively stained with $1 \%$ phosphotungstic acid $(\mathrm{pH}$ 6) and examined with a Philips EM400 electron microscope at $75 \mathrm{kV}$. The range, mean and standard deviation of the virion diameters were calculated by measuring 10 isolated virions.

Preparation of immune sera. Pre-immune sera was collected from 6 New Zealand white rabbits just prior to their injection with purified virus ( 2 rabbits with each virus). Rabbits were injected with $0.5 \mathrm{ml}$ of a $1: 1 \mathrm{mix}$ ture of purified virus and Freund's complete adjuvant into the muscle of each hind leg. After $4 \mathrm{wk}$, the rabbits received a second injection of $0.2 \mathrm{ml}$ of purified virus via the marginal ear vein. The rabbits were bled and the serum collected $1 \mathrm{wk}$ following the final injection. Serum was stored at $4^{\circ} \mathrm{C}$ until used for neutralization and immunofluorescence assays.

Neutralization and immunoiluorescence assays (IFAT). Standard serum neutralization assays of the 3 fish viruses were performed with each of the rabbit sera by plaque reduction tests. Tests were conducted with or without the addition of guinea pig complement. The cross indirect fluorescent antibody tests (IFAT) were conducted in 24-well dishes with virus-infected BF-2 cells. A 24-well plate containing monolayers of BF-2 cells was prepared for each virus. Virus was added at an $\mathrm{MOI}$ of $0.1 \mathrm{PFU}$ cell ${ }^{-1}$ to all but 4 wells of the plate. After 4 d at $20^{\circ} \mathrm{C}$, when the first indications of CPE were evident, the medium was removed and the cell monolayers rinsed with $0.01 \mathrm{M}$ phosphate buffered saline (PBS), pH 7.4. The cells were then fixed by the addition of $1.0 \mathrm{ml}$ of a $40: 60$ acetone-ethanol solution at $-20^{\circ} \mathrm{C}$ for $10 \mathrm{~min}$. The fixative was removed, and the cells were air-dried and then stored at $4^{\circ} \mathrm{C}$. Serial 2 -fold dilutions in PBS (beginning with $1: 10$ ) of each sera were added so that $0.2 \mathrm{ml}$ of each was added to 1 well in each of the 3 virus-infected plates. A replicate aliquot of the lowest anti-serum dilution was placed onto uninfected control cells and pre-immune sera (1:10) was added to 1 well with infected cells. After 30 min at $37^{\circ} \mathrm{C}$, the sera were removed and the wells rinsed 3 times with PBS. A $1: 200$ dilution of goat antirabbit IgG labeled with FITC (fluorescein isothiocyanate) was added to all wells. The conjugate was removed after $30 \mathrm{~min}$ at $37^{\circ} \mathrm{C}$ by 3 rinses with PBS. After air-drying, the wells were examined for the highest dilution of serum at which immunofluorescence was detected. For photography, BF-2 and EPC cells were grown on microscope slides, infected with either the isolate 62.90 or with FV 3 at an MOI of $0.01 \mathrm{PFU} \mathrm{cell}^{-1}$. After $3 \mathrm{~d}$ at $15^{\circ} \mathrm{C}$ the slides were rinsed 3 times with serum-free MEM and fixed with acetone: ethanol as described above. Uninfected control and infected cells were incubated with a 1:500 dilution of anti-62.90 rabbit serum and then with the conjugate as described 
for cross IFAT. After a final rinse, the slides mounted with buffered glycerol were observed with a microscope equipped for fluorescence.

Polyacrylamide gel electrophoresis. The polypeptides of the purified viruses were separated in $10 \%$ acrylamide gels according to Laemmli et al. (1970). A panel of molecular weight markers (BioRad Inc., Richmond, California, USA) was included in the gel. After electrophoresis for $2 \mathrm{~h}$ at $200 \mathrm{~V}$, the gels were stained with $1 \%$ Coomassie Blue (R-250) for $1 \mathrm{~h}$, destained in $40 \%$ methanol $/ 10 \%$ ethanol for $1 \mathrm{~h}$ and then rehydrated in $10 \%$ ethanol $/ 5 \%$ acetic acid. The mobility and number of viral polypeptides were calculated and their molecular weights estimated by comparison to the standards.

\section{RESULTS}

\section{Electron microscopy}

All 3 iridovirus-like agents had similar size and morphology as determined by negative-stained virus preparations. The mean diameters of the particles were consistently 153 to $154 \mathrm{~nm}$ (Table 1). Intact virions were dense and their icosahedral symmetry evident as demonstrated by the position of triangular vertices (Fig. 1). Larger, swollen forms that were more spherical in diameter were also observed in the 13.91 preparation (Fig. 1A). These ranged in size from 175 to $184 \mathrm{~nm}$ and were most likely degenerating virions.

Table 1. Comparison of virion diameters of 3 iridovirus-like agents from fish as partially purified from infected BF-2 cells and stained with $1 \%$ phosphotungstic acid $(n=10$

\begin{tabular}{|cccc|}
\hline Virus & \multicolumn{3}{c|}{$\begin{array}{c}\text { Diameter }(\mathrm{nm}) \\
\text { Mean }\end{array}$} \\
\hline 13.91 & Range & SD \\
62.90 & $148-163$ & 153 & 6.4 \\
59.90 & $141-163$ & 154 & 8.2 \\
& $141-163$ & 153 & 9.0 \\
\hline
\end{tabular}

\section{Neutralization and immunofluorescence assays}

There was no indication of neutralization in sera collected from any of the rabbits immunized with the purified viruses. Addition of complement did not show

Fig. 1. Virions of 3 iridovirus-like agents isolated from fish (A) 13.91 from redfin perch Perca fluviatilis, (B) 62.90 from sheatfish Siluris glanis and (C) 59.90 from catfish Ictalurus melas. Partially purified virus suspensions were stained with $1 \%$ phosphotungstic acid. Scale bar $=200 \mathrm{~nm}$
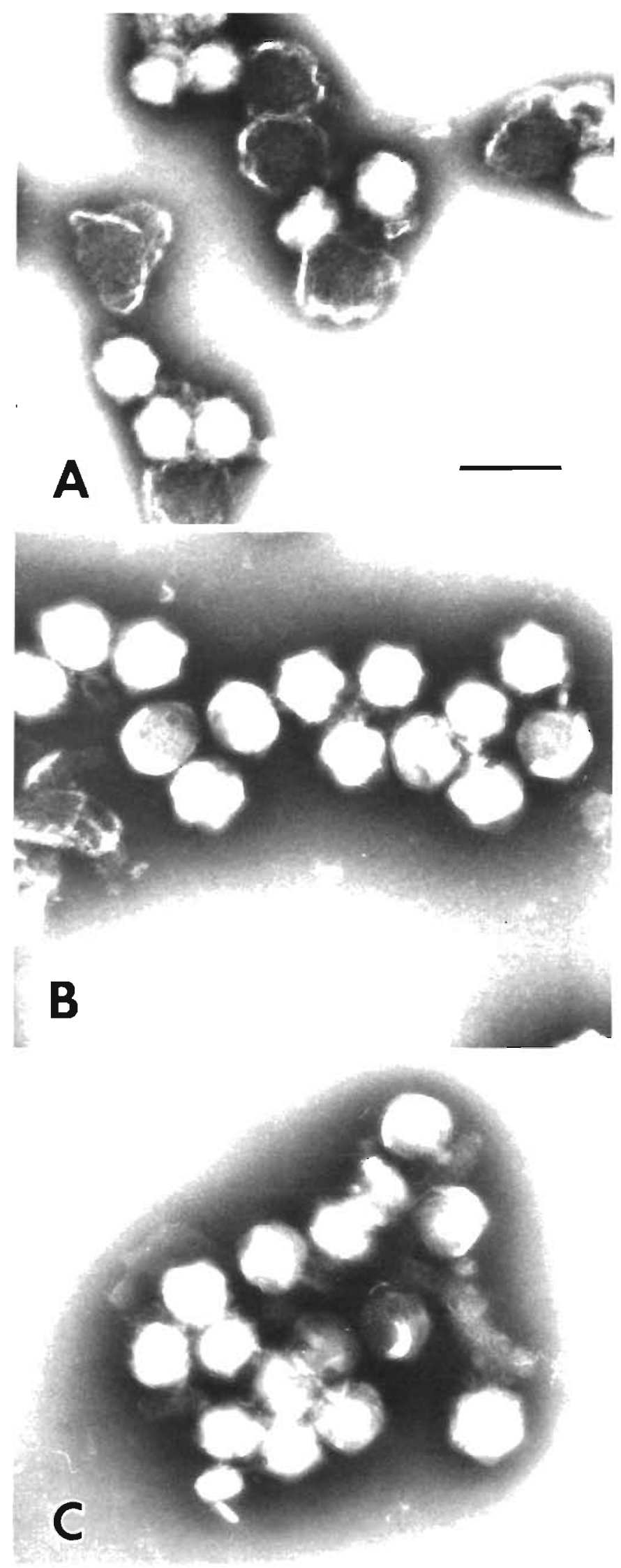

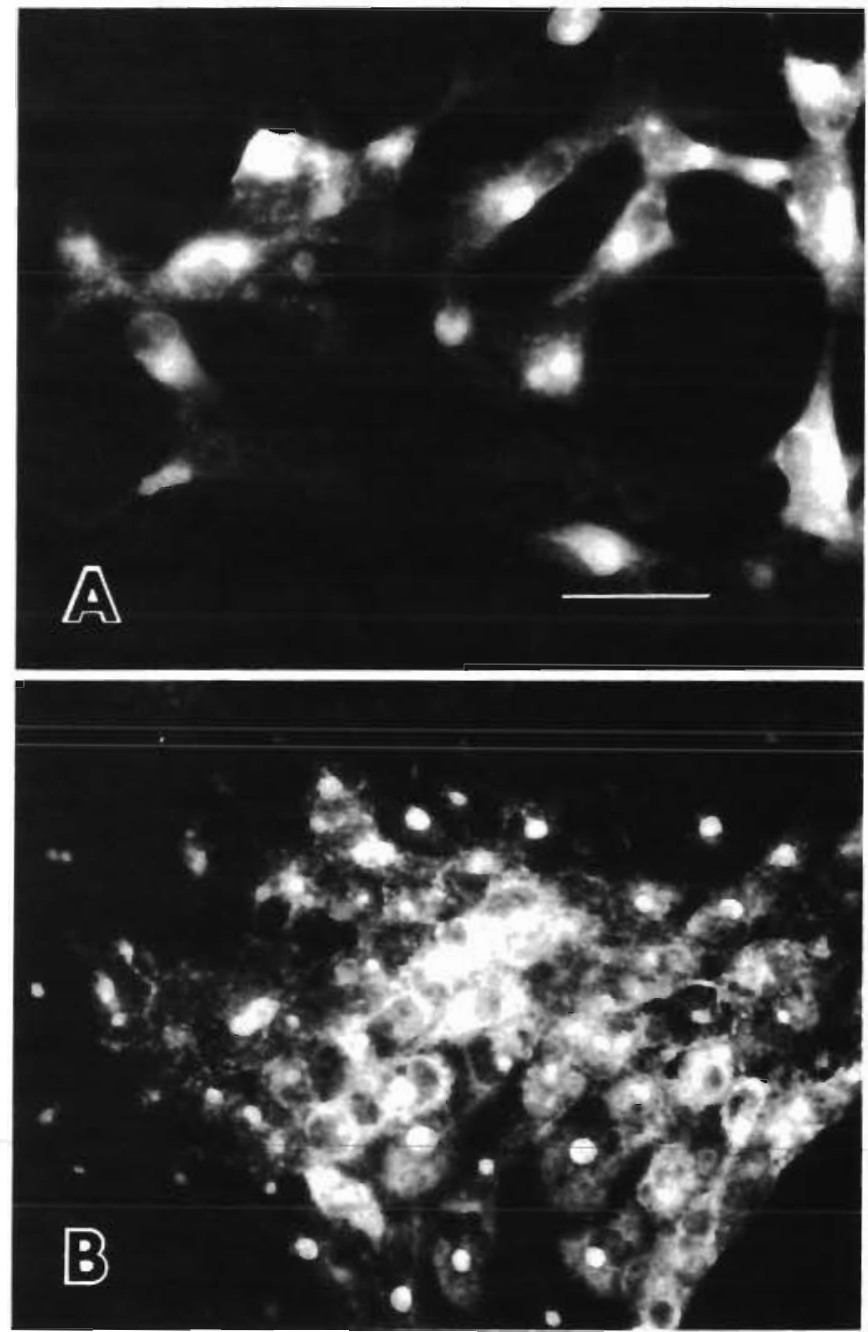

Fig. 2. Indirect immunofluorescence assays using antiserum to the iridovirus-like agent 62.90 . (A) BF-2 cells infected with 62.90; (B) EPC cells infected with FV3. Scale bar $=20 \mu \mathrm{m}$

any effect on the neutralization. All 3 immune sera contained antibodies directed to their respective viral antigens as determined by IFAT (Table 1, Fig. 2A).

Endpoint titers of the sera against homologous virus ranged from 1600 to 12800 (Table 2). The homologous

Table 2. Results of cross indirect immunofluorescence assays with 3 iridovirus-like agents from fish. Endpoints are expressed as the reciprocal of the highest serum dilution at which viral antigens were detected on monolayers of virusinfected BF-2 cells

\begin{tabular}{|c|c|c|c|}
\hline \multirow[t]{2}{*}{ Virus } & \multicolumn{3}{|c|}{ Antiserum } \\
\hline & 13.91 & 62.90 & 59.90 \\
\hline 13.91 & 12800 & 3200 & 3200 \\
\hline 62.90 & 1600 & 1600 & 1600 \\
\hline 59.90 & 1600 & 3200 & 1600 \\
\hline
\end{tabular}

virus and anti-serum reactions for the isolates 13.91 and 59.90 were slightly greater than with the heterologous viruses. The antisera against the isolate 62.90 reacted equally well with all 3 viruses. The staining was confined to the cytoplasm and ranged from diffuse to intense focal fluorescence of elliptical to circular bodies (Fig. 2A). There was no fluorescence detected with control serum taken prior to immunization of the rabbits.

In a separate test, antisera $(1: 500)$ against each of the 3 fish viruses were found to react equally well with their homologous isolates in BF-2 cells or with FV 3-infected EPC cells (Fig. 2B). The staining in FV 3infected cells was similar to that observed with the 3 fish viruses with the exception that the intensely stained circular bodies were more prominent.

\section{Polyacrylamide gel electrophoresis}

The polypeptide profiles of the 3 iridovirus-like agents resembled each other and that of FV 3 (Fig. 3). Either 19 or 20 viral polypeptides were detected in each of the fish viruses compared to 15 in FV 3 (Table 3). Although the polypeptide profiles were similar for the fish and frog viruses, each virus could be distinguished by the mobility of the higher-molecular-weight polypeptides. Of the 4 viruses, the 62.90 and 59.90 strains
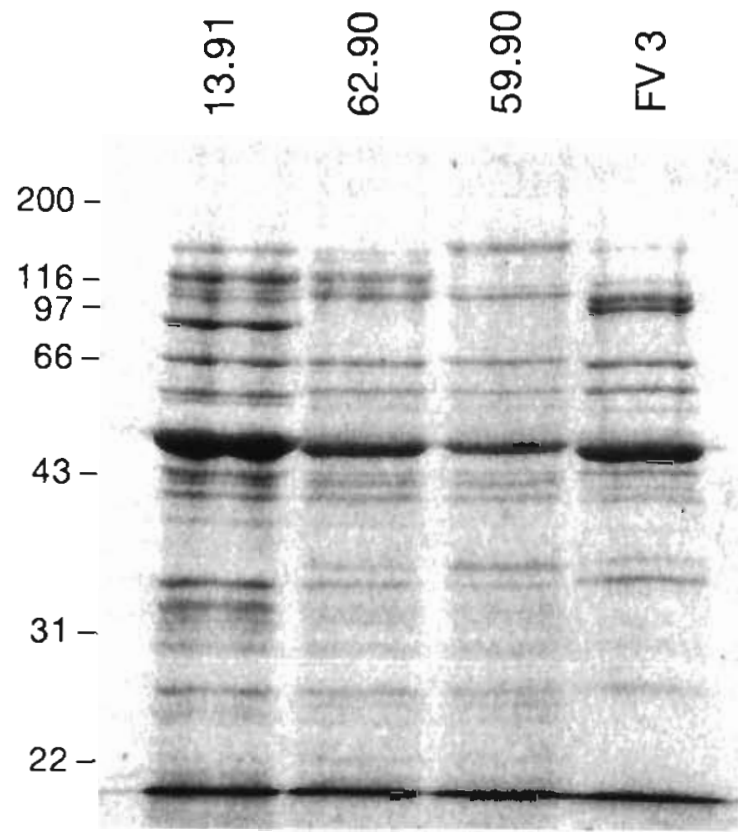

Fig. 3. Virion polypeptides of 3 iridovirus-like agents from fish $(13.91,62.90,59.90)$ and trog virus 3 (FV3) as shown in a Coomassie Blue stained $10 \%$ polyacrylamide gel. Molecular weights are in $\mathrm{kD}$ 
Table 3. Estimated molecular weights $(\mathrm{kD})$ of structural polypeptides of 3 iridovirus-like agents from fish and the amphibian iridovirus FV 3 as determined by electrophoresis in 10\% polyacrylamide gels

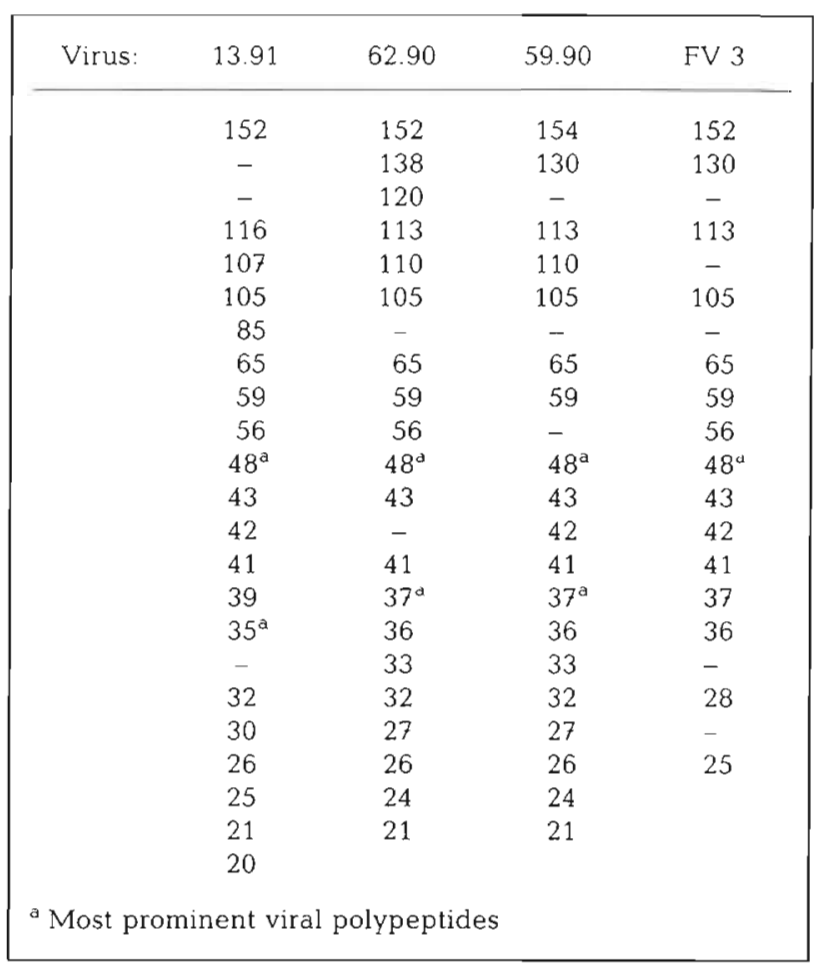

showed the greatest number of identically sized polypeptides, with major differences found in only 5 proteins.

\section{DISCUSSION}

A comparison showed that 3 iridovirus-like agents isolated from fish suffering serious systemic diseases were related with respect to their virion morphology and size, structural proteins and antigenic properties using IFAT. We suggest that these 3 viruses are individual strains of a single group of piscine iridoviruses with strong affinities to members of the genus Ranavirus in the family Iridoviridae.

The family Iridoviridae contains viruses found both among invertebrate (insects) and poikilothermic vertebrate hosts (Devauchelle et al. 1985). These viruses were originally grouped together based on their icosahedral symmetry, large double-stranded DNA genomes and the presence of non-cellular-membranederived envelopes (Kelly \& Robertson 1973). Their unique replication strategy, involving both nuclear and cytoplasmic phases (Murti et al. 1985), has led some to believe they are the missing link between the herpesviruses and poxviruses (Armnentrout \& McAuslan 1974). A majority of the iridoviruses share an associa- tion with the aquatic environment during some stage of their hosts' development and it has been proposed that their internal membrane structure confers the stability observed in aqueous solutions (Kelly 1985). Currently there are 4 genera within the family Iridoviridae (Aubertin 1991). Members of the Iridovirus and Chloriridovirus are found among insects, while viruses belonging to the Ranavirus and Lymphocystivirus are known from amphibians and fish, respectively. A group with goldfish virus, separate from the 4 genera, has also been proposed (Essani \& Granoff 1989). Numerous ranaviruses have been isolated from amphibians, principally from normal adult leopard frogs Rana pipiens (Granoff et al. 1966). The viruses grouped in this genus show a high degree of DNA homology and are pathogenic for both tadpoles and certain toads (Essani \& Granoff 1989). The few comparisons made between amphibian and piscine iridoviruses have indicated limited or no homology and this has led to their current separation into distinct genera (Essani \& Granoff 1989).

The piscine and amphibian viruses share similarities with respect to broad and overlapping host cell line susceptibilities as shown for FV 3 and EHNV (Essani \& Granoff 1989, Langdon 1989). The EHNV also has been shown to infect 7 species of teleost fish following natural or experimental routes of exposure (Langdon 1989). The few comparisons of amphibian and fish iridoviruses (Wolf et al. 1968, Essani \& Granoff 1989) have led to the conclusion that FLDV or lymphocystis virus (Wolf 1962) and GFV, the goldfish iridovirus (Berry et al. 1983), are clearly separable from the amphibian viruses which compose a more homogeneous group. Two genera containing fish viruses in the family Iridoviridae, one including GFV and the other FLDV, were proposed, and the latter was accepted (Aubertin 1991). The results presented in our study, however, indicate that serious fish pathogens may also belong in a third genus (Ranavirus) previously composed solely of amphibian viruses.

The iridoviruses examined in our study were slightly larger than the 130 to $140 \mathrm{~nm}$ reported for members of Ranavirus (Essani \& Granoff 1989) but their symmetry, structure and overall appearance are identical to those reported for FV 3 by Tripier-Darcy et al. (1982). Degenerating virions were commonly observed in our preparations, and these closely resemble FV 3 following pronase treatments (Tripier-Darcy et al. 1982). The virion of FV 3 is complex, with an outer envelope that surrounds a hydrated proteic capsid with an underlying membrane of lipid and protein. A majority of the virions observed in our study lacked a distinct outer envelope (Fig. 1). We presume that this was removed during purification since the chloroform sensitivity of the piscine iridoviruses suggests an important role for this external envelope (Ahne et al. 1989). Structures corres- 
ponding to the external filaments described for Lymphocystivirus (Berthiaume et al. 1984) were not found in our study or in previous examiniations of these 3 piscine iridoviruses as observed within infected cells (Langdon et al. 1986, Ahne et al. 1989, Pozet et al. 1992).

Neutralizing antibodies have been used in attempts to compare ranaviruses. Lehane et al. (1968) compared 8 ranaviruses designated FV 1, 2 and 3, LT 1 to 4 and $\mathrm{L}-4 \mathrm{~b}$, but no antigenic differences were found by neutralization with hyperimmune rabbit serum. The antisera prepared by Lehane et al. (1968) against these ranaviruses was of low titer and often it is difficult to obtain any neutralizing antibodies against iridoviruses. For this reason antigenic comparisons between species are dependent on their cross reactions with nonneutralizing antibodies (Aubertin 1991). The reactivity observed by immunofluorescence with antiserum against the 3 fish iridoviruses in our study and their homologous and heterologous strains indicated the presence of conserved group-specific antigens. Additionally, cross reactions observed with antiserum to the 3 fish viruses with FV 3 further support a common grouping of the fish and amphibian viruses (Fig. 2B).

The numbers and distribution of structural proteins found in the 3 iridoviruses from fish and FV 3 were similar but all of the agents were distinct (Fig. 3, Table 3). Iridoviruses are complex viruses with large genomes, and up to 35 virus-specific polypeptides have been detected with FV 3 (Willis et al. 1977). At least 22 of these polypeptides are found in purified virions of FV 3. While 10 of the FV 3 polypeptides are phosphorylated, no evidence for glycosylated or sulfated proteins has been found (Elliot \& Kelly 1980). The principal capsid polypeptide of ca $48 \mathrm{kD}$ found in FV 3 (TripierDarcy et al. 1982) had similar major counterparts in all 3 fish iridoviruses (Fig. 3). Of the 15 polypeptides of FV 3 detected, 12 were similar in size to those detected in the fish iridoviruses. Of the 19 or 20 polypeptides found in the fish iridoviruses (isolates 59.90 and 62.90), differences were found in only 5 polypeptides, suggesting that these 2 agents are the most closely related of the 4 viruses in our study. The pattern and number of viral polypeptides observed in our study did not resemble those of FLDV or GFV, the only other piscine iridoviruses examined to date (Flugel et al. 1982, Essani \& Granoff 1989). Further evidence at the genome level indicates that EHNV resembles FV 3 in being heavily methylated (Willis \& Granoff 1980, Eaton et al. 1991). We presume a similar genome structure will be found with the 2 iridoviruses from catfish (62.90 and 59.90).

While future studies will be required to further define the similarities and differences between fish and amphibian iridoviruses, our study and that of Eaton et al. (1991) show that related agents exist in each of these aquatic hosts. This prompts questions regarding the evolution and reservoirs of new viral pathogens of both fish and frogs. Secondly, it complicates fish health cuntrol programs which exclude amphibians from inspection. In the only study examining the pathogenicity of an amphibian iridovirus Wolf et al. (1968) did not find the tadpole edema virus (a ranavirus) to be pathogenic for bluegill Lepomis macrochirus, brook trout Salvelinus fontinalis or rainbow trout. Further testing of other species of fish (e.g. catfish and redfin perch) are seemingly warranted. The recent reports of systemic iridovirus infections in both fish and frogs from Europe (Ahne et al. 1989, Fijan et al. 1991) may be indicators of the potential movement or spread of these viruses between species. We can only speculate on the current geographic distribution of the systemic piscine iridoviruses but the transport of amphibians or exotic ornamental fish may be likely reasons for the appearance of similar viruses in Australia and Europe.

Acknowledgements. This work was supported in part by the Aquaculture and Fisheries Program of the University of California, Davis, USA, and the Institut National de la Recherche Agronomique, Jouy-en-Josas, France. Thanks to K. D. Arkush and L. Watson for their assistance.

\section{LITERATURE CITED}

Ahne, W. Ogawa, M. Schlotfeldt, H. J. (1990). Fish viruses: transmission and pathogenicity of an icosahedral cytoplasmic deoxyribovirus isolated from sheatfish (Silurus glanis). J. vet. Med. 37: $187-190$

Ahne, W., Schlotfeldt, H.-J., Ogawa, M. (1991). Iridovirus infection of adults sheatfish (Silurus glanis). Bull. Eur. Ass. Fish Pathol. $11(3): 97$

Ahne, W., Schlotfeldt, H. J., Thomsen, I. (1989). Fish viruses: isolation of an icosahedral cytoplasmic deoxyribovirus from sheatfish (Silurus glanis). J. vet. Med. 36: 333-336

Armentrout, R. W., McAuslan, B. R. (1974). RNA synthesis in cells infected with an icosahedral cytoplasmic deoxyvirus (frog virus 3). J. Virol. 13: 1083-1092.

Armstrong, R. D., Ferguson, H. W. (1989). A systemic viral disease of chromide cichlids, Etropus maculatus Bloch. Dis. aquat. Org. 7: 155-157

Aubertin, A. M. (1991). Family iridoviridae. In: Francki, R. I. B., Fauquet, C. M., Knudson, D. L., Brown, F. (eds.) Classification and nomenclature of viruses. Fifth report of the International Committee on Taxonomy of Viruses. Arch. Virol. (Suppl.) 2: 132-136

Berry, E. S., Shea, T B., Gabliks, J. (1983). Two iridoviruses from Carassius auratus (L.). J. Fish Dis. 6: 501-510

Berthiaume, L., Alain, R., Robin, J. (1984). Morphology and ultrastructure of lymphocystis disease virus, a fish iridovirus, grown in tissue culture. Virology 135: 10-19

Devauchelle, G., Stolz, D. B., Darcy-Tripier, F. (1985). Comparative ultrastructure of Iridoviridae. In: Willis, D. B. (ed.) Current topics in microbiology and immunology. Springer, New York, p. 1-22

Eaton, B. T., Hyatt, A. D., Hengstberger, S. (1991). Epizootic haematopoietic necrosis virus: purification and classification. J. Fish Dis. 14: 157-169 
Elliot, R. M., Kelly, D. C. (1980). Frog virus 3 replication: induction and intracellular distribution of polypeptides in infected cells. J. Virol. 33: 29-51

Essani, K., Granoff, A. (1989). Amphibian and piscine iridoviruses proposal for nomenclature and taxonomy based on molecular and brological properties. Intervirology 30: 23-35

Fijan, N., Matasin, Z., Petrinec, Z., Valpotic, I., Zwillenberg, L. G. (1991). Isolation of an iridovirus-like agent from the green frog (Rana esculenta L.). Vet. Arhiv 61. 151-158

Fijan, N., Sulimanovic, D., Bearzotti, M. Muzinii, D., Zwillenberg, L. D., Chilmonczyk, S., Vauthcrot, J. F., de Kinkelin, P. (1983). Some properties of the epithelioma papillosum cyprini (EPC) line from common carp Cyprinus carpio. Ann. Virol. Inst. Pasteur 134: 207-220

Flugel, R. M., Darai, G., Gelderblom, H. (1982). Viral proteins and adenosine triphosphate phosphohydrolase activity of fish lymphocystis disease virus. Virology 122: 48-55

Granoff, A., Came, P. E., Breeze, D. C. (1966). Viruses and renal adenocarcinoma of Rana pipiens. I. The isolation and properties of virus from normal and tumor tissue. Virology 29: $133-148$

Hedrick, R. P., Groff, J. M., McDowell, T. S., Wingfield, W. H. (1990). An iridovirus from the integument of white sturgeon. Dis. aquat. Org. 8: 39-44

Kelly, D. C. (1985). Insect iridescent viruses. In: Willis, D. B. (ed.) Curr. Topics Microbiol. Immunol. 116: 23-35

Kelly, D. C., Robertson, J. S. (1973). Icosahedral cytoplasmic deoxyriboviruses. J. gen. Virol. 20: 17-41

Laemmli, U. K. (1970). Cleavage of structural proteins during the assembly of the head of bacteriophage T4. Nature Lond. 227: 680-685

Langdon, J. S. (1989). Experimental transmission and pathogenicity of epizootic hematopoietic necrosis virus (EHNV) in redfin perch, Perca fluviatilis and 11 other species of teleosts. J. Fish Dis. 12: 295-310

Langdon, J. S., Humphrey, J. D. (1987). Epizootic haematopoietic necrosis, a new viral disease in redfin perch Perca fluviatilis L. in Australia. J. Fish Dis. 10: $297-298$

Langdon, J. S., Humphrey, J. D., Williams, L. M. (1988).

Editorial responsibility: Managing Editor
Outbreaks of EHNV-like iridovirus in cultured rainbow trout, Salmo gairdneri Richardson, in Australia. J. Fish Dis. 11. 93-96

Langdon, J. S., Humphrey, J. D., Williams, L. M., Hyatt, A. D., Westbury, H. A. (1986). First virus isolation from Australian fish: an iridovirus-like pathogen from redfin perch, Perca fluviatilis L. J. Fish Dis. 9: 263-268

Lehane, D. E., Clark, H. F., Karzon, D. T (1968). Antigenic relationships among frog viruses demonstrated by the plaque reduction and neutralization kinetics test. Virology 34 : $590-595$

Murti, K. G., Goorha, R., Granoff, A. (1985). An unusual replication strategy of an animal iridovirus. Adv. viral Res. 30: $1-19$

Ogawa, M., Ahne, W., Fischer-Scherl, T., Hoffmann, R. W., Schlotfeldt, H. J. (1990). Pathomorphological alterations in sheatfish fry Silurus glanis experimentally infected with an iridovirus-like agent. Dis, aquat. Org. 9: 187-191

Pozet, F., Moussa, A., Torhy, C., de Kinkelin, P. (1992). Isolation and preliminary characterization of a pathogenic icosahedral deoxyribovirus from the catfish IIctalurus melas). Dis. aquat Org. 14 : in press

Tripier-Darcy, F., Braunwald, J., Kirn, A. (1982). Localization of some frog virus 3 structural polypeptides. Virology 116 : $635-640$

Willis, D. B., Goorha, R., Miles, M., Granoff, A. (1977). Macromolecular synthesis in cells infected by frog virus 3. VII. Transcriptional and post-transcriptional regulation of virus gene expression. J. Virol. 24: 326-342

Willis, D. B., Granoff, A. (1980). Frog virus 3 is heavily methylated at $\mathrm{CpG}$ sequences. Virology 107-250-257

Wolf, K. (1962). Experimental propagation of lymphocystis disease of fishes. Virology 18: 249-256

Wolf, K. (1988). Fish viruses and viral diseases. Cornell University Press, Ithaca

Wolf, K., Bullock, G. L., Dunbar, C. E., Quimby, M. C. (1968). Tadpole edema virus: a viscerotropic pathogen for anuran amphibians. J. infect. Dis, 118: 253-262

Wolf, K., Gravell, M., Malsberger, R. G. (1966). Lymphocystis virus: isolation and propagation in centrarchid fish cell lines. Science 151: 1004-1005

Manuscript first received: March 17, 1992 Revised version accepted: June 19, 1992 